\title{
AN ANALYSIS OF THE TAX IMPLICATIONS OF PROSPECTING EXPENDITURE INCURRED BY JUNIOR EXPLORATION COMPANIES IN SOUTH AFRICA
}

\author{
Joline Sturdy* \\ University of South Africa \\ sturdj@unisa.ac.za \\ Christo Cronjé+ \\ University of South Africa \\ cronjcj@unisa.ac.za
}

Received: May 2011

Accepted: March 2013

\begin{abstract}
One of the consequences of the change in the mineral policy of South Africa with the promulgation of the Mineral and Petroleum Resources Development Act 28 of 2002 was the increase in junior exploration companies. Junior exploration companies are mainly involved in prospecting activities. No definition exists for either prospecting or exploration in the Income Tax Act 58 of 1962 (Income Tax Act). The lack of research and case law on the tax treatment of prospecting expenditure by junior exploration companies may result in various interpretations for the treatment of prospecting expenditure. Through critical analysis of specific sections in the Income Tax Act, applicable case law and relevant literature, it is evident that there are different interpretations by junior exploration companies of the treatment of prospecting expenditure from an income tax perspective. The perceived challenges with interpretation of the tax treatment of prospecting expenditure by junior exploration companies create an opportunity for further research.
\end{abstract}

Keywords

Junior exploration companies, Prospecting expenditure, Prospecting rights, Mining operations, Income derived from mining operations, Section 11(a), section 15(b) and section 22 of the Income Tax Act

\#Ms Joline Sturdy is a senior lecturer in the Department of Financial Accounting at the University of South Africa.

+Prof Christo J Cronjé is a professor in the Department of Financial Accounting at the University of South Africa University of South Arica. 


\section{INTRODUCTION}

The lack of definitions of terminology used in section 15 of the Income Tax Act 58 of 1962, as amended (Income Tax Act), research and case law on the treatment of prospecting expenditure by companies not involved in mining operations may result in various interpretations by junior exploration companies in the treatment of prospecting expenditure.

With the promulgation of the Mineral and Petroleum Resources Development Act 28 of 2002 (MPRDA) the mineral rights policy of South Africa changed from a dual private- and stateowned mineral rights policy to a state-owned mineral policy. The objectives of the MPRDA are to give the state the right to exercise sovereignty over and custodianship of the nation's mineral and petroleum resources (Republic of South Africa, 2002). One of the consequences of this change was that a large number of junior exploration companies applied for and received prospecting rights. Junior exploration companies are involved exclusively in prospecting activities (KPMG, 2006). Junior exploration companies are either prospecting for speculative purposes, that is, selling a viable proposition, or they are prospecting with the aim of establishing a mine (KPMG, 2006).

The Income Tax Act contains specific provisions that apply to prospecting expenditure incurred by taxpayers who derive income from mining operations. Prospecting is not defined in the Income Tax Act; however, a definition of mining operations is given. Although the definition of mining operations is very wide, the question arises as to whether mining operations include prospecting activities of junior exploration companies. Depending on the intention of the junior exploration company, the prospecting expenditure incurred may be treated very differently in the case of a speculative intention as opposed to an intention to establish a mine (KPMG, 2006).

The objective of this article is to critically analyse certain sections in the Income Tax Act, specifically those sections dealing with the treatment of prospecting expenditure from a junior exploration company's perspective, and to identify challenges with the interpretation of these sections.

The rest of this article is organised as follows: firstly, the selected methodology is discussed, and this is followed by a review of the current mineral law in South Africa. Thereafter, specific definitions and tax principles applicable to junior exploration companies are outlined. This is followed by a discussion of the nature of prospecting expenditure. Thereafter, the tax consequences of prospecting expenditure for junior exploration companies with a speculative intention or the intention to establish a mine are analysed. Finally, a conclusion and recommendations are presented.

\section{METHODOLOGY}

The research was based on a qualitative analysis of current literature. The research required detailed analysis of specific sections of the Income Tax Act. The specific sections of the Income Tax Act that were analysed included the sections dealing with the general deduction formula, the trading stock provisions and the specific allowances that pertain to deductions from income derived from mining operations. The research also included the analysis of relevant case law of South Africa. Where case law was not available, other relevant literature, such as books, articles, periodicals and other studies, was analysed. 


\section{MINERAL LAW IN SOUTH AFRICA}

Mineral law in South Africa has developed over a period of more than three hundred years (Cawood \& Minnitt, 1998). The origin of mineral law in South Africa started when the Dutch colonised the Cape in 1652, and it has continued to develop until today. The issues relating to the private ownership of the right to mine on one's own land and the control of the right to mine and the mining industry by the State are evident throughout the period. The revision of the dual private- and state-owned mineral rights policy of South Africa was initiated by the new political dispensation of the African National Congress in February 1994 (Cawood \& Minnitt, 1998). Common law principles of privately owned mineral rights were replaced with the concept of state custodianship of mineral rights (Keaton Energy, 2008). Revision of the mineral rights policy ultimately resulted in the promulgation of the MPRDA in 2004. Section 3 of Chapter 2 of the MPRDA (Republic of South Africa, 2002) allows the state to grant prospecting rights to various new investors and role players in the extractive industry of South Africa; this has allowed a significant number of junior exploration companies to become active in this industry (Keaton Energy, 2008).

The chief inspector of mines from the Department of Minerals and Energy (DME) stated in 1997 that mining houses often held the rights to small deposits they did not wish to exploit and to large resources they intended to mine in the future (DME, 1997). This meant that junior exploration companies were not able to enter the extractive industry in South Africa (DME, 1997). Jourdan (cited in Cawood \& Minnitt, 1998:373) is also of the opinion that the large mining houses held almost all mineral rights before the promulgation of the MPRDA. As a result, these mining houses carried out almost all exploration activities in South Africa. Moreover, mining tax reform did not keep up with the mineral rights reform which was put into place by the MPRDA. Mining tax reform was last carried out in the early 1990s (Van Blerck, 1991), when large mining houses carried out the majority of exploration activities.

\section{DEFINITIONS APPLICABLE TO JUNIOR EXPLORATION COMPANIES}

Definitions of terms that are relevant to the prospecting activities of junior exploration companies are provided in the sub-sections below.

\subsection{Junior exploration company}

Van Blerck (1992:9-3) defines a 'junior exploration company' as 'a company that is involved exclusively in prospecting and exploration activities.' The intentions of junior exploration companies are either prospecting for speculative purposes, that is, selling a viable proposition, or they are prospecting with the aim of establishing a mine (KPMG, 2006). It is important to determine the intention of a junior exploration company as the tax treatment of the prospecting expenditure incurred may be treated very differently.

\subsection{Mining and mining operations}

The definitions of 'mining' and 'mining operations' in terms of section 1 of the Income Tax Act require a mineral to be won from the soil or from any substance or constituent thereof (Republic of South Africa, 1962). The Income Tax Act contains specific provisions that apply to prospecting 
expenditure incurred by taxpayers who derive income from mining operations. The question therefore arises as to whether these definitions of 'mining' and 'mining operations' include the prospecting activities of junior exploration companies.

\subsection{Prospecting and exploration}

Even though no definition for either prospecting or exploration is included in the Income Tax Act, definitions can be found in the MPRDA and International Financial Reporting Standards (IFRS). Chapter 1 of the MPRDA defines 'prospecting' as the intentional searching for any mineral by means of any method that disturbs the surface earth, in order to establish the existence of any mineral and to determine the extent and economic value of such mineral (Republic of South Africa, 2002).

IFRS 6, Exploration for and evaluation of mineral resources, refers to 'exploration' as 'the search for mineral resources, after an entity has obtained the legal rights to explore in a specific area, as well as the determination of the technical feasibility and commercial viability of extracting the mineral resources' (IASB, 2011). The terms 'exploration' and 'prospecting' are equivalent terms, although the term 'exploration' is used in IFRS 6 (IASB, 2011), whereas the term 'prospecting' is used in both the MPRDA and the Income Tax Act.

\subsection{Prospecting expenditure}

Section 15(b) of the Income Tax Act provides examples of prospecting expenditure. These include expenditure on surveys, boreholes, trenches, pits and other prospecting work preliminary to the establishment of a mine as well as other expenditure that is incidental to the prospecting operations (Republic of South Africa, 1962).

\section{TAX PRINCIPLES}

Tax principles that are relevant to the prospecting activities of junior exploration companies are provided in the sub-sections below.

\subsection{General deduction formula}

Section 11 (a) read with section $23(\mathrm{~g})$ of the Income Tax Act is known as the general deduction formula and provides the starting point for amounts to be deducted from income. Section 11(a) of the Income Tax Act determines that a taxpayer is allowed to deduct from income derived from carrying on a trade any expenditure and losses actually incurred in the production of income, provided that such expenditure is not of a capital nature (Republic of South Africa, 1962). In other words, the requirements of section 11 of the Income Tax Act are, firstly, that a taxpayer must be carrying on a trade; secondly, that income must be derived from such trade and, thirdly, that expenditure of a capital nature must be excluded. However, section ll(a) of the Income Tax Act must be read together with section 23 of the Income Tax Act, which disallows the deduction of certain types of expenditure (Republic of South Africa, 1962). Section 23(g) of the Income Tax Act prohibits the deduction of any moneys claimed as a deduction to the extent that the moneys are not laid out or expended for the purpose of a trade (Republic of South Africa, 1962). 


\subsection{Capital allowances}

Since capital expenditure is not deductible in terms of the general deduction formula, the Income Tax Act grants certain capital allowances. Allowances on moveable assets are largely provided for in section 11 (e) and section $12 \mathrm{C}$ of the Income Tax Act. Allowances on immoveable assets are largely provided for in section 13 and section 12D of the Income Tax Act.

The Income Tax Act contains specific allowances in section 15 that pertain to deductions from income derived from mining operations. Section 15(a) of the Income Tax Act provides for accelerated capital allowances for mining taxpayers (Republic of South Africa, 1962). The quantum of the allowance is determined with reference to the provisions in section 36 of the Income Tax Act. Section 36 of the Income Tax Act deals with capital expenditure incurred subsequent to the establishment of a mine. Section 15(b) of the Income Tax Act specifically deals with expenditure incurred by a taxpayer on prospecting activities prior to the establishment of a mine (Republic of South Africa, 1962).

\subsection{Trading stock}

'Trading stock' is defined in section 1 of the Income Tax Act as 'anything acquired, produced, constructed, manufactured or assembled with a revenue intention, that is, for resale at a profit' (Republic of South Africa, 1962). The second part of the trading stock definition specifies that the proceeds from the disposal should form part of the taxpayer's gross income. In conjunction with the definition, section 22 of the Income Tax Act determines that when taxable income is calculated, the value of trading stock at the beginning and the end of the year of assessment must be taken into account (Republic of South Africa, 1962). The reason why the value of trading stock must be taken into consideration is that in terms of section 11 (a) of the Income Tax Act the expenditure incurred results in an allowable deduction in terms of section $11(a)$ of the Income Tax Act, as such expenditure is incurred in the production of income.

Section 15A of the Income Tax Act specifically deals with amounts that should be taken into account in respect of trading stock derived from mining operations. Trading stock relating to mining operations includes anything that is won or acquired during the course of mining operations for the purpose of extraction, processing, separation, refining, beneficiation, manufacture and sale or exchange (Republic of South Africa, 1962).

\subsection{Income derived from mining operations}

As mentioned in section 5.2 above, section 15 of the Income Tax Act pertain to deductions from income derived from mining operations. Two steps are necessary to determine income derived from mining operations (Van Blerck, 1992:10-2). Firstly the terms 'mining' and 'mining operations' need to be identified and secondly it is necessary to determine what income is derived from these activities (Van Blerck, 1992:10-2). The first step has already been discussed in section 4.2 above. As regards to the term 'derived from', do these words require a close connection between the mining operation and the income (Van Blerck, 1992:10-2)? In Western Platinum Limited v Commissioner for South African Revenue Services (CSARS) 67 SATC 1 (at 614) the interpretation of the phrase 'income derived from mining operations' was confirmed to mean income derived from the business of mining operations in the sense of extracting minerals from the soil. Accordingly, only income directly derived from or connected to the business of mining operations would qualify as mining income. 


\subsection{Investment income}

Junior exploration companies earn interest on funds that are held pending commencement of the prospecting activities programme. Such income is regarded as non-mining income, as the underlying funds are non-mining assets (Van Blerck, 1992). As discussed in section 5.4 above, in Western Platinum Limited $v$ CSARS 67 (supra) it was confirmed that income qualifies as mining income only if it is directly connected to the business of extracting minerals from the soil. Therefore, the interest earned by junior exploration companies on funds is non-mining income.

\section{NATURE OF PROSPECTING EXPENDITURE}

The definition of gross income in section 1 of the Income Tax Act requires a distinction between two different types of transactions, namely revenue or capital (Republic of South Africa, 1962). The Income Tax Act does not define the term 'of a capital nature' but, over the years, the courts have established various methods which they apply in order to determine the nature of expenditure as either capital or revenue.

\subsection{Capital versus revenue}

The nature of capital expenditure may be explained in terms of the fact that capital is the income-producing machine and the product of this machine is income (Van Blerck, 1992). Capital expenditure will generally result in the creation of a lasting benefit for the company (KPMG, 1993). The principle that capital expenditure should create a lasting benefit was confirmed in Phalaborwa Mining Company Limited v Secretary for Inland Revenue 35 SATC 159. The company incurred expenditure in order to build a barrage across a river merely to provide the company with the water necessary to bring forward its production date by eight months. This expenditure was held to be of revenue nature as it did not create an enduring benefit. Expenditure of a capital nature produces income or a lasting benefit to the taxpayer for a reasonably long period.

The principle that capital is the income-producing machine was confirmed in New State Areas Ltd v Commissioner of Inland Revenue 14 SATC 155. The court clarified the distinction of revenue and capital nature. If the expenditure is incurred for the purpose of acquiring a capital asset for the business, it is capital expenditure. If, on the other hand, it is part of the cost incidental to the performance of the income-producing operations, as distinguished from the equipment of the income-producing machine, it is revenue expenditure. In Matla Coal Ltd v Commissioner of Inland Revenue 48 SATC 223 the court held that all property, including mining and mineral rights, may be held with a view to exploiting the rights as income-producing capital assets or alternatively with a view to realisation as part of a profit-making scheme, in which case they assume the character of trading stock.

\subsection{Intention}

In Elandsheuwel Farming (Edms) Bpk v Sekretaris van Binnelandse Inkomste 39 SATC 163 it was determined that three main tests commonly apply in the determination of the distinction between capital and revenue, namely the original intention at acquisition and sale, the nature of the agreement, that is, scheme of profit making, and whether it constituted fixed or floating capital. In Commissioner of Inland Revenue $v$ Stott 3 SATC 253 the judge highlighted the fact that 
the intention of the taxpayer is an important factor to take into account when the nature of expenditure is determined, but consideration must also be given to all the factors.

\subsection{Conclusion}

To establish the distinction between the revenue and capital nature of expenditure the South African courts have identified intention as being critical in the determination of the nature of expenditure. Therefore, the nature of prospecting expenditure depends on the intention of the junior exploration company.

A junior exploration company is prospecting for speculative purposes when the prospecting right was obtained with the intention of selling the right at a profit, that is, a scheme of profit making, the prospecting expenditure incurred will then be of a revenue nature for taxation purposes (Van Blerck, 1992). The prospecting expenditure incurred did not create an enduring benefit and is incidental to the performance of the income-producing machine.

It may be argued that if a junior exploration company has the objective of establishing a mine in the future, the prospecting expenditure is being incurred for the purpose of producing income in the future (Van Blerck, 1992). When a junior exploration company is prospecting to establish a mine rather than for 'speculative purposes', the prospecting expenditure incurred by the junior exploration company could be regarded as being of a capital nature for taxation purposes. The prospecting expenditure is part of the income-producing machine and will result in the creation of a lasting benefit if successful.

\section{SPECULATIVE INTENTION: TAX IMPLICATIONS OF PROSPECTING EXPENDITURE INCURRED BY JUNIOR EXPLORATION COMPANIES}

As discussed in section 6.3 above, the prospecting expenditure incurred by a junior exploration company for speculative purposes is of a revenue nature. Therefore, the general deduction formula as discussed in section 5.1 above may be considered for the prospecting expenditure incurred, but section 23B of the Income Tax Act provides that section 11(a) cannot be considered in respect of any expenditure or loss of a type for which a deduction or allowance may be granted under any other provision of the Income Tax Act (Republic of South Africa, 1962). Although section 15(b) of the Income Tax Act grants a deduction in respect of prospecting expenditure, this deduction relates to prospecting expenditure incurred prior to establishing a mine. Even though junior exploration companies with a speculative intention are performing prospecting activities as discussed in section 4.3 above, by intentional searching for any mineral in order to establish the existence of any minerals, their intention is not to establish a mine by winning these minerals from the soil, but to sell a viable proposition to establish a mine to a third party. Therefore, section 1l(a) of the Income Tax Act can be considered for prospecting expenditure of a revenue nature. The requirements of section 11 of the Income Tax Act are, firstly, that a taxpayer must be carrying on a trade, secondly, that income must be derived from such trade and, thirdly, that expenditure of a capital nature be excluded (Republic of South Africa, 1962).

The first requirement of section 11 of the Income Tax Act is that a taxpayer must be carrying on a trade. The definition of trade in section 1 of the Income Tax Act includes every trade, business and venture (Republic of South Africa, 1962). In Burgess $v$ Commissioner for Inland Revenue 55 
SATC 185 the principle that the definition of trade should be given the widest possible interpretation was described as well-known. It was also highlighted in Burgess $v$ Commissioner for Inland Revenue (supra) that the definition of trade is in any event not necessarily exhaustive. It also pointed out that a venture has considerable risk of loss as well as chance of a gain, but that a venture does not have to be risky to be included in the definition of a trade. Therefore activities of junior exploration companies who obtain prospecting rights for speculative purposes do fall within the ambit of the definition of trade.

The second requirement of section 11 of the Income Tax Act is that income must be derived from such trade. Prospecting activities are time consuming, costly and full of risk: it may take a number of years before a payable mineral deposit is discovered or the prospecting activities may be unsuccessful in discovering a payable mineral deposit in the future. Due to the time and risk involved in prospecting activities junior exploration companies may have a non-profit-making trade. In De Beers Holdings (Pty) Ltd v Commissioner of Inland Revenue 47 SATC 229 the judge accepted that a company could carry on a non-profit-making trade, although the trade must generate some sort of business benefit. Even though prospecting activities are proven to be unsuccessful the expenditure was incurred exclusively for the purpose of the trade. In Sub-Nige/ Ltd $v$ Commissioner of Inland Revenue 15 SATC 381 it was maintained that it is necessary only that expenditure be incurred for the purpose of producing income and the simple fact that income is not produced does not prohibit the deductibility of the expense.

Lastly, the requirements of section 11 of the Income Tax Act provide that expenditure of a capital nature be excluded. As discussed in section 6.3, the tax consequences of prospecting activities when incurred for speculative purposes are of a revenue nature. Therefore, the prospecting expenditure incurred would be deductible as expenditure incurred in the production of income in terms of section 11(a) of the Income Tax Act.

The prospecting expenditure incurred is deductible in terms of section 11(a) of the Income Tax Act, but the timing of the deduction is an issue. The issue is whether the prospecting expenditure incurred relates to further costs to develop prospecting rights into finished products and therefore incurred for the purpose of sale and subject to the trading stock provisions in the Income Tax Act or merely costs incurred for the possible or potential purpose of sale and therefore subject to the general deduction formula. The abovementioned issue relating to the timing of the deduction of prospecting expenditure are discussed in sections 7.1, 7.2 and 7.3.

\subsection{Opinion 1: Timing subject to section 22 of the Income Tax Act}

If junior exploration companies obtain prospecting rights for the purpose of selling the rights at a profit, then the proceeds of the disposal would be of a revenue nature and would be included in the gross income of the junior exploration companies. The prospecting rights qualify as trading stock according to the definition in section 1 of the Income Tax Act.

Section 22(1) of the Income Tax Act determines the value of trading stock to be taken into account in determining taxable income as the cost price, less such amount by which the value of the trading stock has been diminished by reason of damage, deterioration, change in fashion, decrease in market value or any other reason satisfactory to the Commissioner (Republic of South Africa, 1962). If subsequent to obtaining the prospecting rights the junior exploration companies perform prospecting activities to find payable mineral deposits for the purpose of sale, then consideration should be given to section 22(3)(a)(i) of the Income Tax Act which provides that the cost of trading stock includes any further costs in getting such trading stock 
into its existing condition and location (Republic of South Africa, 1962). Section 22(3)(b) of the Income Tax Act determines that such further costs would include costs in terms of generally accepted accounting practice approved by the Commissioner (Republic of South Africa, 1962). IAS 2, Inventories, determines that the cost of inventories includes all costs of purchase, cost of conversion and other costs incurred to bring the inventories to their present condition (IASB, 2011). It may be argued that the subsequent prospecting expenditure is necessary further costs to develop the prospecting right into their present condition as a finished product. The knowledge gained from the further prospecting activities could therefore constitute a 'thing' that formed part of the finished product. KPMG (2006) and KPMG (1993) are also of the opinion that the timing of the deduction of prospecting expenditure would be subject to section 22 of the Income Tax Act.

\subsection{Opinion 2: Timing subject to a combination of section $11(a)$ and section 22 of the Income Tax Act}

It was observed in De Beers Holdings (Pty) Ltd $v$ Commissioner of Inland Revenue (supra) that the definition of trading stock may be divided into two parts. The first part lays emphasis upon the purpose for which something is produced, manufactured or acquired, namely, for the purpose of manufacture or sale. The second requirement determines that when something is disposed of the proceeds constitute gross income in terms of section 1 of the Income Tax Act. The specific purposes are limited to manufacturing, sale and exchange by the taxpayer (Faber, 2008).

According to the MPRDA a prospecting right has to be obtained before any prospecting activities can be performed. Therefore, it may be argued that the purpose of obtaining a prospecting right is twofold. Firstly, the purpose is to obtain access to a certain area to enable the junior exploration company to perform prospecting activities to confirm the existence of any minerals. Secondly, the purpose is to sell the prospecting right to a third party.

As discussed above, the purpose of obtaining a prospecting right is, firstly, to obtain access to an area to perform prospecting activities. The definition of trading stock lays emphasis upon the purpose for which something is produced, manufactured or acquired. Accordingly, it may be argued that the purpose of the prospecting expenditure incurred is firstly to do research and obtain knowledge of the possible minerals in an area, before a decision can be made to sell the prospecting right as a viable proposition. The prospecting activities produce knowledge for the possible or potential purpose of sale. Therefore, the prospecting expenditure is not incurred for the purpose of manufacture or sale. The prospecting expenditure incurred would consequently be deductible as expenditure incurred in the production of income in terms of section 11 (a) of the Income Tax Act. Van Blerck (1992) also confirms that the prospecting expenditure is incurred in the production of income and will therefore be deductible in terms of the general deduction formula in section 11 (a) of the Income Tax Act.

As discussed above the purpose of obtaining a prospecting right is twofold. Secondly, the intention of selling the right is present; therefore the initial costs incurred to obtain the prospecting right qualify as trading stock according to the definition in section 1 of the Income Tax Act. Van Blerck (1992) is also of the opinion that when a company is trading in mineral or prospecting rights the rights constitute trading stock. 


\subsection{Opinion 3: Timing not subject to section 22 of the Income Tax Act}

It should also be noted that KPMG (1993) is of the opinion that the initial costs incurred to obtain the prospecting rights as well as the subsequent prospecting expenditure are deductible as expenditure incurred in the production of income under section 11 (a) of the Income Tax Act. Although the possibility exists that the prospecting expenditure incurred at any stage could be considered as trading stock, in practice SARS are unlikely to insist on the latter treatment (KPMG, 1993).

Section 7.4 illustrates through an example the difference in timing of the deduction of prospecting expenditure as discussed above in sections $7.1,7.2$ and 7.3 .

\subsection{Speculative intention: examples}

Junior Exploration Company obtained a prospecting right in 2011 with a cost of Rl 000. Junior Exploration Company incurred R5 000 prospecting expenditure in 2011. Junior Exploration Company earned interest income of R7 000 in 2011. During the latter part of 2011 the prospecting activities confirmed a viable mineral deposit. No further exploration costs were incurred. The prospecting right was sold in 2012 for R20 000. The effect of these transactions on the taxable income of Junior Exploration Company for the years ended February 2011 and 2012 is illustrated in TABLE 1 below.

TABLE 1: Speculative intention: tax implications of prospecting expenditure examples

\begin{tabular}{|c|c|c|c|c|}
\hline & & $\begin{array}{l}\text { Opinion } 1 \\
\qquad R\end{array}$ & $\begin{array}{c}\text { Opinion } 2 \\
\qquad R\end{array}$ & $\begin{array}{l}\text { Opinion } 3 \\
\qquad R\end{array}$ \\
\hline \multirow[t]{5}{*}{2011} & Gross income - sales & Nil & $\mathrm{Nil}$ & $\mathrm{Nil}$ \\
\hline & Gross income - other income & 7000 & 7000 & 7000 \\
\hline & Section $11(a)$ deduction - expenditure & $(6000)$ & $(6000)$ & $(6000)$ \\
\hline & Section 22(1) closing stock - add to income & 6000 & 1000 & Nil \\
\hline & Taxable income & 7000 & 2000 & 1000 \\
\hline \multirow[t]{5}{*}{2012} & Gross income - sales & 20000 & 20000 & 20000 \\
\hline & Section $11(a)$ deduction - expenditure & Nil & Nil & Nil \\
\hline & $\begin{array}{l}\text { Section } 22(2) \text { opening stock - deduct from } \\
\text { income }\end{array}$ & $(6000)$ & $\left(\begin{array}{llll}1 & 0 & 0 & 0\end{array}\right)$ & Nil \\
\hline & Section 22(1) closing stock - add to income & $\mathrm{Nil}$ & Nil & Nil \\
\hline & Taxable income & 14000 & 19000 & 20000 \\
\hline
\end{tabular}

Source: Authors' example

The total taxable income for years 2011 and 2012 in opinions 1 to 3 is R21 000 , but in opinion 1 the subsequent prospecting expenditure may be deducted only in the year the prospecting right is disposed of, while in opinion 2 and 3 the subsequent prospecting expenditure is deductible in the year in which it is incurred. Although in this example the prospecting rights were sold within two years, prospecting activities are time consuming and can last for a number of years before a 
viable proposition is found. Opinions 2 and 3 will allow the junior exploration company to deduct the subsequent exploration cost immediately; this will reduce taxable income in the year the costs were incurred. The difference in the timing of the deductions will have an impact on the cash flow of the junior exploration company and will result in a different rate of return on the investment of the junior exploration company.

\subsection{Speculative intention: fruitless prospecting expenditure}

Due to the speculative nature of prospecting activities it is not unusual for prospecting activities to be unsuccessful. If prospecting expenditure was included as part of trading stock and subsequently shown to be fruitless, the value of the trading stock would have diminished. According to section 22(1) of the Income Tax Act, the value of trading stock should be reduced by the amount by which the value of the trading stock has diminished (Republic of South Africa, 1962). This allows junior exploration companies to reduce the value of the trading stock by the fruitless prospecting expenditure that was included as part of trading stock once the prospecting activities prove unsuccessful. TABLE 2 below illustrates the effect of prospecting activities proven unsuccessful. Similar information was used as per TABLE 1 , but at the beginning of 2012 the prospecting activities were proven unsuccessful.

TABLE 2: Speculative intention: tax implications of unsuccessful prospecting expenditure examples

\begin{tabular}{llcc}
\hline & & Opinion 1 & Opinion 2 \\
& & $R$ & $R$ \\
\hline 2012 & Gross income - sales & $\mathrm{Nil}$ & $\mathrm{Nil}$ \\
& Section 11(a) deduction - expenditure & $\mathrm{Nil}$ & $\mathrm{Nil}$ \\
& Section 22(2) opening stock - deduct from income & $(6000)$ & $(1000)$ \\
& Section 22(1) closing stock - add to income & $\mathrm{Nil}$ & $\mathrm{Nil}$ \\
\cline { 2 - 3 } & Taxable income & $(6000)$ & $(1000)$ \\
\cline { 2 - 3 }
\end{tabular}

Source: Authors' example

The total taxable income for years 2011 and 2012 in both opinion 1 and opinion 2 is Rl 000 . As discussed above, prospecting activities are time consuming and can last for a number of years before prospecting activities are proven unsuccessful. The difference in the timing of the deductions will have an impact on the cash flow of the junior exploration company and will result in a different rate of return on the investment of the junior exploration company. Fruitless prospecting expenditure has no effect in the treatment of prospecting expenditure according to opinion 3 , as there is no prospecting expenditure treated as trading stock.

\section{INTENTION TO ESTABLISH A MINE: TAX IMPLICATIONS OF PROSPECTING EXPENDITURE INCURRED BY JUNIOR EXPLORATION COMPANIES}

As discussed in section 5.2, section 15(b) of the Income Tax Act specifically deals with expenditure incurred by a taxpayer on prospecting activities prior to the establishment of a 
mine. Section 15(b) of the Income Tax Act is applicable to junior exploration companies performing prospecting activities with the intention to establish a mine. Section 15(b) of the Income Tax Act allows for the deduction of expenditure incurred in the year of assessment on prospecting operations within the Republic (Republic of South Africa, 1962). The deduction includes expenditure incurred on surveys, boreholes, trenches, pits and other prospecting work preliminary to establishing a mine. Prospecting is not defined in the Income Tax Act except that the Income Tax Act refers to prospecting expenditure as expenditure incurred prior to the establishment of a mine (Van Zuydam, 2008). Section 15(b) of the Income Tax Act does not distinguish between the revenue or capital nature of prospecting expenditure. Therefore all expenditure incurred during prospecting, including capital expenditure prior to the establishment of a mine, is deductible. However, in terms of the second requirement of section 15(b) of the Income Tax Act, this deduction should be deducted only from income derived by the taxpayer from mining operations.

The provision of section 15(b) of the Income Tax Act contains three specific restrictions, namely the instalment restriction, the class of mine restriction and the capital redemption restriction (Van Blerck, 1992). In terms of the instalment restriction (which excludes diamond mining), the Commissioner may determine that the prospecting expenditure be deducted in a series of instalments (Republic of South Africa, 1962). In the case where a company derives income from different classes of mining operations, the class of mine restriction determines that the deduction under section 15(b) of the Income Tax Act shall be made from the income derived from such class of mining operation and in such proportions as determined by the Commissioner (Republic of South Africa, 1962). In terms of the capital redemption restriction any expenditure which has been allowed to be deducted in terms of section 15(b) of the Income Tax Act shall not be allowed as capital expenditure in terms of section 36 of the Income Tax Act (Republic of South Africa, 1962).

The deduction allowed according to section 15(b) of the Income Tax Act is against income derived from mining operations. It is therefore important to define 'income derived from mining operations'. As discussed in section 5.4, in Western Platinum Limited v CSARS (supra) the court confirmed that only income directly derived from or connected to the business of mining operations would qualify as mining income. As discussed in section 4.2 , the question arises as to whether mining operations include prospecting activities of junior exploration companies. In the Murchison Exploration and Mining Co Ltd $v$ Commissioner of Inland Revenue 10 SATC 143 the taxpayer was a newly established company that was prospecting in order to establish a mine. The taxpayer incurred prospecting costs in its first year of operation while, during the same period, the taxpayer earned interest on funds. The tax authorities wanted to tax the interest at the higher tax rate applicable to gold mining income rather than at the lower rate of tax applicable to other income. In Murchison Exploration and Mining Co Ltd v Commissioner of Inland Revenue (supra) Maritz J stated (at 148) that prospecting and exploration work are merely methods to test if a property is worthwhile mining; therefore when a company is entirely involved in prospecting and exploration activities, its activities do not constitute mining operations. Accordingly, the prospecting activities of junior exploration companies exclusively involved in basic prospecting do not constitute mining operations and therefore do not meet the second requirement of section 15(b) of the Income Tax Act.

The issue is whether it is necessary for the taxpayer to meet the second requirement, i.e. conducting mining operations, in order to obtain the deduction. There are currently two opinions relating to prospecting expenditure incurred prior to the commencement of mining operations (KPMG, 2006). These opinions are discussed below. 


\subsection{Opinion 1: Prospecting expenditure creates an assessed loss}

As stated above, the deduction in accordance with section 15(b) of the Income Tax Act is granted from income derived from mining operations. This wording indicates that the taxpayer must be earning income from mining operations and that the deduction is limited to that income (Van Blerck, 1992).

The deduction in accordance with section 15(b) of the Income Tax Act must be allowed if the taxpayer is conducting mining operations, without the existence of income from mining operations (Van Blerck, 1992). This reasoning is maintained by the fact that the wording used in the foreword to the general deduction formula is similar to the foreword used in section 15 of the Income Tax Act (Van Blerck, 1992). The definition of an assessed loss in section 20(2) of the Income Tax Act defines an assessed loss as any amount by which the deductions admissible under section 11 exceed the income in respect of which they are so admissible (Republic of South Africa, 1962). Since it is possible for a taxpayer conducting mining operations to earn no income from such operations it follows that the deduction in accordance with section 15(b) of the Income Tax Act is allowable and will create an assessed loss from mining operations (Van Blerck, 1992).

However, even if a junior exploration company's activities do not constitute mining operations, a case for allowing the deduction can still be made. In Sub-Nigel Ltd v Commissioner of Inland Revenue (supra) it was maintained that it is necessary only that expenditure be incurred for the purpose of producing income and the simple fact that income is not produced does not prohibit the deductibility of the expense under section 11 (a) of the Income Tax Act. It may be argued that although prospecting activities of junior exploration companies do not constitute mining operations, providing they have the objective of establishing a mine in the future, the prospecting expenditure is being incurred for the purpose of producing income from mining operations in the future (Van Blerck, 1992). On this basis it may be argued that the deduction allowed in accordance with section 15(b) of the Income Tax Act for prospecting expenditure should be carried forward in terms of the assessed loss provision until income from mining operations occurs (Van Blerck, 1992).

Van Blerck (1992) is also of the opinion that a reasonable case can be made for the deduction of such prospecting expenditure against non-mining income earned in the interim, for example interest income. This opinion is confirmed by KPMG (2006), who state that the prospecting expenditure creates an assessed loss, resulting in the junior exploration company setting off income from other trades against such assessed loss. One could argue it is unlikely that the intention of section 15(b) of the Income Tax Act is to significantly disadvantage a company seeking to establish a mine compared to an existing mining company seeking to expand its operations (Van Blerck, 1992).

\subsection{Opinion 2: Prospecting expenditure should be carried forward, to be deducted against future mining income}

During November 1986 the Margo Commission appointed a technical committee, the Marais Committee, to investigate matters relating to mining taxation (Marais Committee, 1988). The Marais Committee (Marais Committee, 1988) commented on section 15(b) of the Income Tax Act and identified a problem in respect of prospectors who are prospecting to establish a mine but are not yet involved in mining operations. The problem would be that there is no mining income 
against which to set off the deduction (Marais Committee, 1988). The Marais Committee (Marais Committee, 1988) confirmed that junior exploration companies prospecting to establish a mine would be permitted to use the allowance of section 15(b) of the Income Tax Act only once they had earned mining income. The Marais Committee (Marais Committee, 1988) also confirmed that the value of the allowance according to section 15(b) of the Income Tax Act is limited to the income against which the deduction may be offset.

KPMG (2006) agreed with the view of the Marais Committee, as another alternative treatment of prospecting expenditure, but was of the opinion that where mining income is insufficient, the deduction may generate an assessed loss from mining operations. Platmin Limited (2011) also confirmed that prospecting expenditure incurred prior to the commencement of production should be carried forward until commencement of production. Therefore, a junior exploration company will carry forward all prospecting expenditure incurred in prior years until their prospecting activities are proven successful and a mine is established that is earning mining income. On the face of it, the wording of section 15(b) of the Income Tax Act indicates that the taxpayer must be earning income from mining operations for the deduction to be allowed.

\subsection{Expenditure incurred in obtaining prospecting rights}

The deduction allowed according to section 15(b) of the Income Tax Act does not apply to expenditure of an initial nature (KPMG, 1993). Expenditure of an initial nature may include acquisition of land or costs involved in obtaining prospecting rights. Prospecting expenditure includes expenditure to obtain prospecting rights that is capital expenditure and not deductible, as no special deduction exists (Van Blerck, 1992). Section 36(e) of the Income Tax Act includes any expenditure incurred in terms of the mining right pursuant to the MPRDA, as an accelerated capital allowance if the trade constitutes mining (Republic of South Africa, 1962). Junior exploration companies incur expenditure to obtain a prospecting right, not a mining right, and prospecting activities of junior exploration companies do not constitute mining operations. As discussed in section 6.3, the expenditure to obtain a prospecting right is of a capital nature when a junior exploration company obtained the rights with the intention of establishing a mine. Therefore, the expenditure will not qualify as a deduction under section 11(a) of the Income Tax Act.

A prospecting right is included in the definition of an asset in accordance with the Eighth Schedule of the Income Tax Act. The definition of an asset in accordance with the Eighth Schedule of the Income Tax Act includes property of whatever nature, whether moveable or immovable, and a right or interest of whatever nature to or in such property (Republic of South Africa, 1962). Although there is no capital allowance in accordance with the Income Tax Act for expenditure incurred on prospecting rights, the expenditure will form part of the base cost of an asset in terms of the Eighth Schedule of the Income Tax Act.

Section 8.4 illustrates through an example the effect that the different opinions as discussed in sections 8.1 and 8.2 will have on junior exploration companies.

\subsection{Intention to establish a mine: examples}

Junior Exploration Company obtained a prospecting right in 2011 with a cost of Rl 000. Junior Exploration Company incurred R8 000 prospecting expenditure in 2011 and R10 000 in 2012. Junior Exploration Company earned interest income of R7 000 in 2011 and R15 000 in 2012. The 
effect of these transactions on the taxable income of Junior Exploration Company for the years ended February 2011 and 2012 is illustrated in TABLE 3 below.

TABLE 3: Intention to establish a mine: tax implications of prospecting expenditure examples

\begin{tabular}{|c|c|c|c|}
\hline & & $\begin{array}{c}\text { Opinion } 1 \\
R\end{array}$ & $\begin{array}{c}\text { Opinion } 2 \\
R\end{array}$ \\
\hline \multirow[t]{5}{*}{2011} & Gross income - mining & Nil & Nil \\
\hline & Section income - non-mining & 7000 & 7000 \\
\hline & Section 15(b) deduction - prospecting expenditure & $(8000)$ & Nil \\
\hline & Section 36(e) deduction - prospecting right & Nil & Nil \\
\hline & Assessed (loss)/Taxable income & 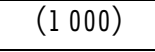 & 7000 \\
\hline \multirow[t]{7}{*}{2012} & Gross income - mining & Nil & Nil \\
\hline & Gross income - non-mining & 15000 & 15000 \\
\hline & Section 15 (b) deduction - prospecting expenditure & $(10000)$ & Nil \\
\hline & Assessed loss 2011 & $\left(\begin{array}{llll}1 & 0 & 0 & 0\end{array}\right)$ & Nil \\
\hline & Taxable income & 4000 & 15000 \\
\hline & $\begin{array}{l}\text { Calculation of prospecting expenditure to be carried } \\
\text { forward, to be deducted against future mining } \\
\text { income }\end{array}$ & Nil & 18000 \\
\hline & Eighth Schedule asset base cost - prospecting right & 1000 & 1000 \\
\hline
\end{tabular}

Source: Authors' example

Opinion 1 allows Junior Exploration Company to deduct the prospecting expenditure in the year in which it is incurred against non-mining income, while opinion 2 carries forward the prospecting expenditure until such time as mining income is earned. The difference in the timing of the deductions will have an impact on the cash flow of the junior exploration company and will result in a different rate of return on the investment of the junior exploration company.

\subsection{Intention to establish a mine: fruitless prospecting expenditure}

If prospecting expenditure incurred during the year of assessment is deemed fruitless, one may argue that the fruitless prospecting expenditure was not incurred prior to the establishment of a mine and therefore does not qualify as prospecting expenditure in terms of section 15(b) of the Income Tax Act. Furthermore, the fruitless prospecting expenditure did not result in an incomeproducing machine, nor did it create a lasting benefit to the junior exploration company. It is therefore of a revenue nature. Section 11(a) of the Income Tax Act can thus be considered for the deduction of fruitless prospecting expenditure of a revenue nature.

As discussed in section 6.3, prospecting expenditure incurred by a junior exploration company with the intention of establishing a mine is of a capital nature. As mentioned in section 8 above, section 15(b) of the Income Tax Act allows a deduction of prospecting expenditure of revenue or capital nature before the establishment of a mine. Therefore, even if prospecting expenditure was incurred in a previous year of assessment and is deemed fruitless in the current year of 
assessment it was already allowed as a deduction in the year it was incurred in accordance of section 15(b) of the Income Tax Act.

When the prospecting activities are fruitless the prospecting right will be scrapped. According to paragraph 11 of the Eighth Schedule of the Income Tax Act scrapping of an asset is defined as a disposal of the asset. The assessed capital loss created by the scrapping of the prospecting right is carried forward to be deducted at a future date against future capital gains.

\section{TRADING STOCK DERIVED FROM MINING OPERATIONS}

Section 15A of the Income Tax Act specifically deals with trading stock related to mining operations. This includes anything that is won or in any other manner acquired during the course of mining operations. As discussed earlier, neither junior exploration companies with speculative intentions nor junior exploration companies with the intention of establishing a mine constitute mining operations. Therefore, section 15A of the Income Tax Act is not applicable to junior exploration companies.

\section{CONCLUSION}

It is evident that junior exploration companies can interpret sections in the Income Tax Act dealing with the treatment of prospecting expenditure differently. From the analysis of specific sections in the Income Tax Act, applicable case law and relevant literature, the intention of a junior exploration company is key in determining the tax treatment of prospecting expenditure.

Firstly, when a junior exploration company is prospecting for speculative purposes, it was found that prospecting expenditure is deductible in terms of section 11(a) of the Income Tax Act. The issue is whether the timing of the deduction is subject to section 22 of the Income Tax Act. The challenge with the interpretation of section 22 of the Income Tax Act is whether the purpose of the prospecting expenditure incurred is for sale or only to produce knowledge for the possible or potential purpose of sale. The interpretation of section 22 of the Income Tax Act has an influence on the timing of the deduction that in turn has an effect on the cash flow of the junior exploration company.

Secondly, when a junior exploration company is prospecting with the intention of establishing a mine, it was found that prospecting expenditure is deductible in terms of section 15(b) of the Income Tax Act. The deduction allowed according to section 15(b) of the Income Tax Act is against income derived from mining operations, but the activities of a junior exploration company do not constitute mining operations. The challenge with the interpretation of section 15(b) of the Income Tax Act is whether the prospecting expenditure incurred by a junior exploration company creates an assessed loss which may be used against non-mining income or whether the prospecting expenditure incurred prior to establishing a mine should be carried forward until commencement of production. Again, the interpretation of section 15(b) of the Income Tax Act has an influence on the timing of the deduction, which in turn has an effect on the cash flow of the junior exploration company. 


\section{RECOMMENDATIONS}

It is recommended that junior exploration companies take cognisance of the fact that the intention of prospecting either for speculative purposes or with the aim of establishing a mine has a major impact on the treatment of the prospecting expenditure incurred.

It is suggested that the perceived challenges with the interpretation by junior exploration companies of the timing of the deduction of prospecting expenditure under section 22 of the Income Tax Act be taken into account as tax planning opportunities. Furthermore, the perceived challenge of whether income from mining operations must be earned before the deduction of section 15(b) of the Income Tax Act is allowed and that such deduction is limited to mining income also creates tax planning opportunities.

\section{LIST OF REFERENCES}

Burgess v Commissioner for Inland Revenue, 1993 4) SA 161 (A), 55 SATC 185.

Cawood, F.T. \& Minnitt, R.C.A. (1998). A historical perspective on the economics of the ownership of mineral rights ownership. The Journal of the South African Institute of Mining and Metallurgy, 98(7), pp. 369-376.

Commissioner for Inland Revenue v Stott, 1928 AD 252, 3 SATC 253.

De Beers Holdings (Pty) Ltd v Commissioner for Inland Revenue, 1986 (1) SA 8 (A), 47 SATC 229.

Department of Minerals and Energy (DME). (1997). New developments in government's thinking on mineral rights by D Bakker, chief inspector of mines. [Online] Available:

http://www.info.gov.za/speeches/1997/09050×20297.htm. (Accessed 17 March 2011).

Elandsheuwel Farming (Edms) Bpk v Sekretaris van Binnelandse Inkomste, 1978 (1) SA 101 (A), 39 SATC 163.

Faber, P.C. (2008). An analysis of the tax implications of ore stockpiling in the mining industry. Unpublished master's dissertation, University of Pretoria: Pretoria.

International Accounting Standards Board (IASB). (2011). A guide through International Financial Reporting Standards as issued at 1 July 2011. London: IFRS Foundation.

Keaton Energy. (2008). Explanation of mining title as it applies in South Africa. [Online] Available: http://www.keatonenergy.co.za/im/files/CPR 5 Conclusion glossary 01apr08.pdf. (Accessed 16 March 2011).

KPMG. (1993). A guide to mining taxation in South Africa. South Africa: KPMG Aiken \& Peat.

KPMG. (2006). Trading stock: speculators vs investors. Integritax, (77). [0nline] Available:

http://www.saica.co.za/integritax/2006/1365_Trading_stock_speculators_vs_investors.htm.

(Accessed 20 June 2011).

Matla Coal Ltd v Commissioner for Inland Revenue, 1987 (1) SA 108 (A), 48 SATC 223.

Murchison Exploration and Mining Co Ltd v Commissioner for Inland Revenue, 1938 TPD 421, 10 SATC 143.

New State Areas Ltd v Commissioner for Inland Revenue, 1946 AD 610, 14 SATC 155. 
Phalaborwa Mining Company Limited v Secretary for Inland Revenue, 1973 (3) SA 819 (A), 35 SATC 159.

Platmin Limited. (2011). Mining legislation. [Online]. Available:

http://www.platmin.com/p/legislation.asp. (Accessed 18 0ctober 2011).

Republic of South Africa. (1962). Income Tax Act 58 of 1962. Pretoria: Government Printer.

Republic of South Africa. Technical Committee on Mining Taxation (Marais Committee). (1988). Report of the technical committee on mining taxation. Pretoria: Government Printer. Chairman: G Marais.

Republic of South Africa. (2002). Mineral and Petroleum Resources Development Act 28 of 2002. Pretoria: Government Printer.

Sub-Nigel Ltd v Commissioner for Inland Revenue, 1948 (4) SA 580 (A), 15 SATC 381.

Van Blerck, M.C. (1991). Spotlight on mining tax. Journal of the South African Institute of Mining and Metallurgy, 91 (5), pp. 219.

Van Blerck, M.C. (1992). Mining Tax in South Africa. Rivonia: Taxfax CC.

Van Zuydam, H. (2008). The alluvial diamond industry: A critical analysis of the capital cost allowances. Unpublished Magister Commercii (Taxation) dissertation, University of Pretoria: Pretoria.

Western Platinum Limited v Commissioner for South African Revenue Services, [2004] 4 All SA 611 (Supreme Court of Appeal), 67 SATC 1. 